\title{
Compliance to Therapeutic regimen Among geriatric Patients with Heart Failure at Assiut City Hospitals
}

\author{
Tasneem A. Shoulkamy ${ }^{1}$, Rabaa H. Hassanen ${ }^{2}$ \& Hanan A. Abozeid ${ }^{3}$. \\ ${ }^{1}$ Demonstrator Gerontological Nursing Department, Faculty of Nursing, Assiut University, Egypt. \\ ${ }^{2}$ Associate Professor Community Health Nursing Department, Faculty of Nursing, Assiut University, Egypt. \\ ${ }^{3}$ Lecturer Gerontological Nursing Department, Faculty of Nursing, Assiut University, Egypt.
}

\begin{abstract}
Heart failure patients require comprehensive care that involves drugs controlling and intentensive. Health teaching about the significance of suitable nutrition, consistent exercise, symptoms control, and fluid checking. This study aimed to assess compliance to therapeutic regimen among elderly patients with heart failure in Assiut City hospitals. Subjects and method: Descriptive research design was conducted. The total sample size was 280 elderly patients by using software EPI /Info, version 3, 3 who were selected by quota from 3 outpatients in Assiut City. Two tools were used; first, structured interview questionnaire, and heart failure compliance questionnaire scale. Results: it was found $59.3 \%$ of elderly patients were male, with a mean age as $65.10 \pm 6.12,56.1 \%$ had poor knowledge scores, $66.8 \%$ were non-compliant with measuring weight and 58.9\% and 53.9\% respectively of them were non-compliant with avoiding drinking excessive fluid and following a low sodium diet. Also, illustrated significant relation among all items of compliance with patients' knowledge except compliance with medication. Conclusion: More than half of studied elderly patients had poor knowledge scores and this was correlated with noncompliance to therapeutic regimen among elderly patients. Recommendations: More studies should be implemented to assess patient's compliance and health education program for elderly about importance of compliance to therapeutic regimen.
\end{abstract}

Keywords: Therapeutic, Regimen, Compliance \& Elderly Patients With Heart Failure.

\section{Introduction}

Aging is known as a risk factor for most human diseases.( Agarwal \& Baur, 2011) All over the world the total number of elderly people was 901 million in $2015(12.3 \%)$ of the population. This expected to increase to 1.4 billion (16.5) in 2030. By 2050 the universal number of elderly individuals will be more than twofold the number of elderly individuals in 2015 around 2.1 billion (World population ageing, 2015) In eastern Mediterranean region(EMRO) the number of elderly individuals was 26.8 million representing $5.8 \%$ of the total population in 2000.In 2050 this percent will increase to become $15 \%$ of total population (AlShaali \& Al Jaziri, 2014) In Egypt the elderly people account for $1.2 \%$ from total world population and the percent of elderly individuals was $6.27 \%$ in 2006.as population and it was $6.9 \%$ in 2015 it will increase to be $9.2 \%$ in 2021. By 2050 it is expected to reach $20.8 \%$ (Sweed, 2016).

Aging is accompanied with continuing buildup of comprehensive change of molecular and cellular impairment. With time, this impairment leads to regular decline in physical capacity, increase danger of illness, and overall weakness of individual's ability. Although these changes are inevitable (WHO, 2015).

The heart undergoes complex changes with age resulting in function and role and decline in heart reserve. These changes involve loss of elasticity, decrease ability of heart to push blood, heart become atrophy, and decline myocardial cells. (Alam, 2017). With aging there is rise in width of left ventricle wall, hypertrophy of left ventricle wall, decrease size of left ventricle (Karavidas et al., 2010) and extension of left atrium (Bolton \& Rajkumar, 2011) Regarding heart valves, all heart valves may rise in their boundaries. But aorta valve is the most one showing most changes. There is calcification in aorta, $80 \%$ of elderly people show sclerosis of aortic valve (Karavidas et al., 2010). Aorta becomes expanded \& extends and losses its elasticity, increasing risk of atherosclerosis (Bolton \& Rajkumar, 2011).

Heart failure is long-term heath disorder that hurts about 5 million people in US. It is an end result of heart diseases; and irreversible condition but symptoms can be controlled. (Burggraf et al., 2014). Patients with heart failure experience difficult breathing, edema and weakness; these symptoms have bad impact on quality of life, activities of daily living and ability of self-care (kazer \& Murphy, 2015, Chan et al., 2016).

Heart failure patients require complex care that involves drugs controlling and teaching about the significance of suitable nutrition, consistent exercise, symptoms control, and fluid checking. This care of failure puts financial burden on health care system and families. It costs about $60 \%$ of health care budget 
(Burggraf et al., 2014) Patient's compliance to interventions don't necessary mean adherence to drug but there are some factors that must be taken into consideration such as nutrition, physical activity, fluid checking and some changes in life style. Lack of patient's compliance is a commonly recognized issue. Although Non-compliance means that patients don't stick to drugs, nutrition and other factors as recommended yet also it means that health care provider don't follow rules or standards of care. Noncompliance to drugs, nutrition leads to bad heart failure signs in some condition may result in hospital admission (AL-khadher \&Fadl-Elmula, 2015).

\section{Significance of the study}

Unsuccessful self-management of patients with HF is a mean reason of recurrent hospitalization, severe illness and death, in addition to high cost. Selfmanagement ill people-initiated does that aid preserve and enhance bodily welfare. It includes eating low sodium diet and fluid, measuring weight, and regular exercises, proper rest. Recent new researches on patient's HF through 15 nations showed that $50-80 \%$ of persons seldom follow these guidelines. Specified self-management is vital to the effective care of HF (Zhang et al., 2015).

According to new (HF) strategies, alteration of salt and water consumption is a significant nonpharmacological commendation for HF patients. Nonadherence to these recommendations is related to medical unsteadiness and rise rate of rehospitalization or mortality mostly because of fluids excess Nieuwenhuis et al., (2011).

The gerontological nurse has significant role in enhancing status of heart failure patients. There are many roles that nurse does to enhance patient's outcome. By assessment nurse know patient's condition that involves increase in weight, difficulty in breathing, compliance to medications and ability to self-care. Patient's education another role of nurse about good nutrition that involves sodium control, low fat and fluid restriction. Nurse gives direction to patients about daily activity living (Pi \& Hu, 2016).

\section{Aim of the study}

This study aimed to assess therapeutic compliance among elderly patients with heart failure in out patient's clinic at Assiut City hospitals

\section{Research question}

1. Do geriatric patients with H.F comply with therapeutic regimen?

2. Is there correlation between patients' knowledge and therapeutic compliance among studied elderly patients with heart failure?
3. What is a relation between therapeutic compliance and sociodemographic characteristics as studied elderly patients with heart failure?

\section{Materials and Method}

Research design

Descriptive research design was used.

\section{Setting}

The present study was conducted in three cardiology outpatient clinics at Assiut city hospitals. Assiut city consist of 4 hospitals namely Assiut University Hospital, El Mabara Hospital, Assiut general hospital (El-shmala) and El Eman general hospital. The study was conducted in three outpatient cardiology clinics only, which include Assiut university hospital, Assiut general hospital (El- shmala) and El Eman general hospital. El Mabara hospital was excluded because its administration refused to participate in the study.

Sampling and sample size: The total number of the study consisted of 280 patients selected from previous mentioned settings. Quota sample for all geriatric patients with heart failure patients (male/female) was used. The total number of patients in all Assiut city hospitals approximately 1020 patients per year, flow rate of patients per month in these hospitals as (Assiut university hospital includes was (30) patients per month, Assiut general hospital (20) patients per month and El Eman general hospital (15) patients per month). By using software EPI /Info, version 3, 3 with $95 \%$ confidence interval (CI), the estimated sample size found to be 280 patients. One Third of patients were selected from each hospital of three hospitals only .It was divided as the following:

\begin{tabular}{|c|c|c|c|}
\hline Hospital & $\begin{array}{c}\text { Number of } \\
\text { patients }\end{array}$ & $\begin{array}{c}\text { Sample } \\
\text { size }\end{array}$ & $\begin{array}{c}\text { Sample } \\
\text { percentage }\end{array}$ \\
\hline $\begin{array}{c}\text { Assiut } \\
\text { university } \\
\text { hospital }\end{array}$ & 360 & 129 & $46.1 \%$ \\
\hline $\begin{array}{c}\text { Assiut general } \\
\text { hospital }\end{array}$ & 240 & 86 & $30.7 \%$ \\
\hline $\begin{array}{c}\text { El- Eman } \\
\text { general } \\
\text { hospital }\end{array}$ & 180 & 65 & $23.2 \%$ \\
\hline Total & 780 & 280 & $100 \%$ \\
\hline
\end{tabular}

Inclusion criteria

1- Geriatric patients aged 60 years and above diagnosed with heart failure.

2- Able to communicate.

Two study tools were used for data collection after reviewing relevant literature.

Tool I: An Interview Structured Questionnaire was developed for data collection, it includes sociodemographic characteristics as, age, sex, residence, marital status, income, occupation, and level of education......etc (Abdeltwab scale, 2004). 
Medical history of heart failure such as smoking and presence of other chronic diseases as hypertension, diabetes, atherosclerosis and renal disease.........etc based on (Walker et al., 2014) and patient's knowledge about heart failure such as definition, signs \&symptoms, risk factors, medications and management of disease (Walker et al., 2014) Total scoring for knowledge was 36 grades. A correct response was scored 1 grade and incorrect response scored zero. The score of each item summed-up and then converted into percent score (Poor $=$ score $<60 \%$, satisfactory $=$ score $60-80 \%$, good $=$ score $>80 \%$ ).

Tool II: A modified revised Heart Failure Compliance Questionnaire scale (AL-khadher \& Fadl-Elmula, 2015). It considers 6 items. It is a 3Point scale (1=rarely; $2=$ half of time; $3=$ often). To assess patient's compliance to medications, diet, fluid restriction, exercise, daily weight, and follow up. Patients were divided two groups; the first group was compliant if they applied often, and the second group was non-compliant if they applied half of the time and rarely.

\section{Operational phase}

An official letter approval was obtained from the dean of faculty of nursing to director of Assiut university hospital (outpatient cardiology clinic), director of Assiut general (El -shamla) hospital and director of El -Eman general hospital. The letter included a permission to carry out the study and explained the purpose and nature of the study. Confidentiality of the information and oral consent from elderly patients for participation in the study was done. The elderly has ethical right to agree or refuse to participate in the study, the purpose discussed to the patients before data collection.

Pilot study was carried out before starting data collection on $10 \%$ of elderly patients to test clarity, feasibility of questionnaire and estimated the time needed for filling it. This sample was excluded from the total sample. Then the necessary modifications were done and final form was developed and used in data collection.

Validity of the sheet: The revised Heart Failure Compliance Questionnaire scale was reviewed by (5 experts), from community health nursing and gerontological nursing staff in Assiut University to assess and evaluate the sheets items to secure the validity of the sheet. Modifications were done according to the directions of the experts committee. Reliability was analyzed by Cronbach's alpha the value was 0.900 .

Data Collection: The study started in $1^{\text {st }}$ of February to the end of August 2017; data were collected from Assiut university hospital, Assiut general hospital (El- shamla) and El Eman general hospital for seven months. The researcher collected data three days per week (Tuesday, Wednesday and Thursday), 4 hours from 9 am to $1 \mathrm{pm}$ and the average number which interviewed was 3-4 elderly patients per day. At ElEman general hospital from $1^{\text {st }}$ of February to end of March, Assiut general hospital from $1^{\text {st }}$ of April to end of May and Assiut university hospital from $1^{\text {st }}$ of Jun to the end of August. The purpose and nature of the study was explained to each patient who agree to participate in the study, oral informed consent was obtained from them and they were assured about confidentiality and privacy that the information will be used only for the purpose of research. Each patient was individually interviewed. The researcher asked patients and record the answer in the Questionnaire sheet at the outpatients clinic of the previous mentioned setting. The approximate time spent during the filling of sheet was around 30-45 minutes.

Statistical analysis: Data were computerized and analyzed by computer programme SPSS (ver.18). Data were presented by using descriptive statistics in the form of frequencies and percentages or means \pm standard deviations for qualitative data. Quantitative data were compared using Independent samples ttest for comparisons among two groups. Qualitative variables were compared using chi-square test to determine significance.

\section{Ethical considerations}

Confidentiality of the information and oral consent from elderly patients for participation in the study were done. The elderly has the right to agree or refuse participation in the study; the purpose was discussed with the patients before data collection. 
Results

Table (1): Distribution of studied sample according to their personal characteristics.

\begin{tabular}{|c|c|c|}
\hline Items & No. $(n=280)$ & $\%$ \\
\hline \multicolumn{3}{|l|}{ Age: (years) } \\
\hline $60-<65$ & 158 & 56.4 \\
\hline $65-<70$ & 64 & 22.9 \\
\hline$\geq 70$ & 58 & 20.7 \\
\hline Mean \pm SD (Range) & \multicolumn{2}{|c|}{$65.10 \pm 6.12(60.0-93.0)$} \\
\hline \multicolumn{3}{|l|}{ Sex: } \\
\hline Male & 166 & 59.3 \\
\hline Female & 114 & 40.7 \\
\hline \multicolumn{3}{|l|}{ Patient education: } \\
\hline Illiterate & 119 & 42.5 \\
\hline Read \& write & 47 & 16.8 \\
\hline Basic & 68 & 24.2 \\
\hline Secondary & 32 & 11.4 \\
\hline University & 14 & 5.0 \\
\hline \multicolumn{3}{|l|}{ Marital status: } \\
\hline Single & 5 & 1.8 \\
\hline Married & 161 & 57.5 \\
\hline Widow & 110 & 39.3 \\
\hline Divorced & 4 & 1.4 \\
\hline \multicolumn{3}{|l|}{ Current Occupation } \\
\hline Housewife & 105 & 37.5 \\
\hline Unemployed & 58 & 20.7 \\
\hline Farmer & 54 & 19.3 \\
\hline Skilled worker & 28 & 10.0 \\
\hline Free business & 26 & 9.3 \\
\hline Worker & 9 & 3.2 \\
\hline \multicolumn{3}{|l|}{ Residence } \\
\hline Rural & 205 & 73.2 \\
\hline Urban & 75 & 26.8 \\
\hline \multicolumn{3}{|l|}{ Living with family: } \\
\hline Alone & 5 & 1.8 \\
\hline With family & 275 & 98.2 \\
\hline Social Class: & & \\
\hline Low & 46 & 16.4 \\
\hline Middle & 183 & 65.4 \\
\hline High & 51 & 18.2 \\
\hline \multicolumn{3}{|l|}{ Presence of care giver } \\
\hline Yes & 152 & 54.3 \\
\hline No & 128 & 45.7 \\
\hline
\end{tabular}




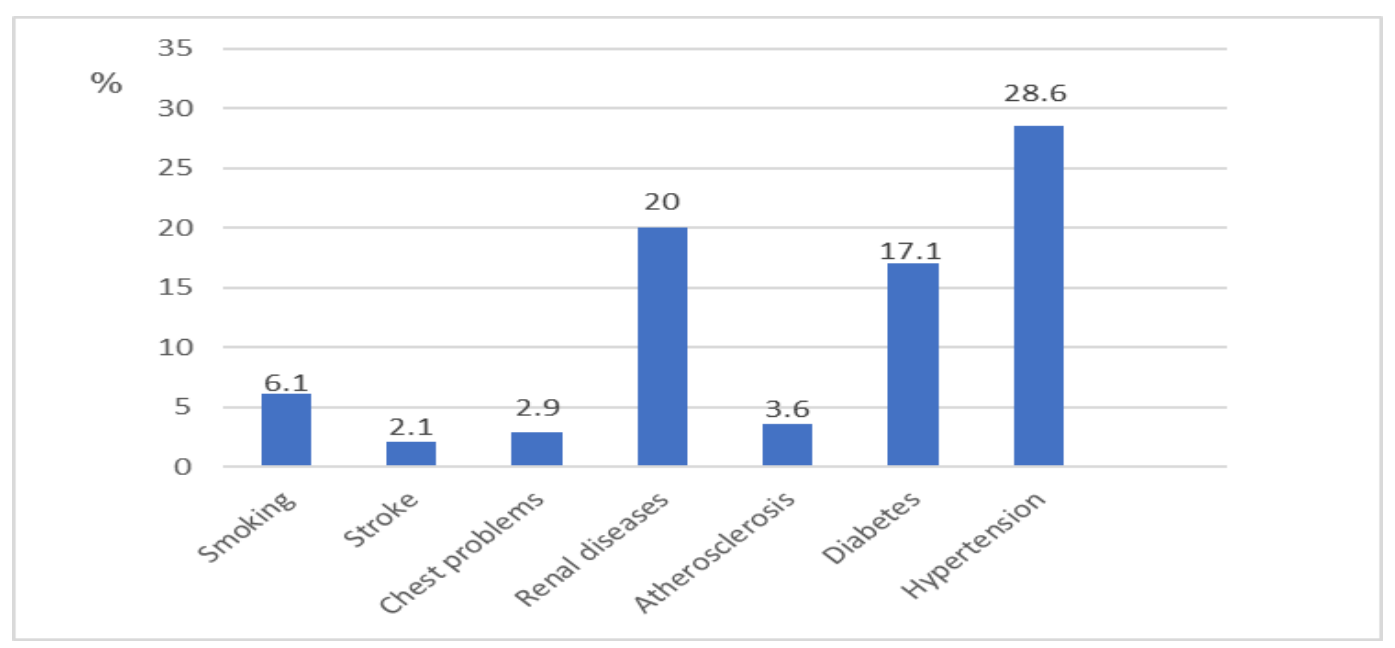

Figure (1): History of chronic diseases \& smoking among elderly patients with heart failure.

Table (2): Distribution of studied sample according to present history of heart failure.

\begin{tabular}{|l|c|c|}
\hline \multicolumn{1}{|c|}{ Items\# } & No. $\mathbf{~ ( n = ~ 2 8 0 )}$ & \% \\
\hline Duration of heart failure disease (years) & & \\
$\mathbf{<} \mathbf{2}$ & 84 & 30.0 \\
$\mathbf{2}-\mathbf{4}$ & 104 & 37.1 \\
$\mathbf{>}$ & 92 & 32.9 \\
\hline Patient's complain & 270 & 96.4 \\
Difficult breathing & 240 & 85.7 \\
Chest pain & 91 & 32.5 \\
Fatigue & 95 & 33.9 \\
Edema & 20 & 7.1 \\
Sleep apnea & & \\
\hline Previous heart operation & 80 & 28.6 \\
Yes & 200 & 71.4 \\
No & & \\
\hline Using pacemaker & 13 & 4.6 \\
Yes & 267 & 95.4 \\
No & & \\
\hline
\end{tabular}

Table (3): Distribution of studied sample according to patient's knowledge about heart failure.

\begin{tabular}{|l|c|c|}
\hline \multicolumn{1}{|c|}{ Items\# } & \multicolumn{2}{|c|}{ No. $(\mathbf{n = 2 8 0})$} \\
\hline Definition of heart failure: & \multicolumn{2}{|c|}{} \\
\hline Correct & 131 & 46.8 \\
\hline Incorrect & 149 & 53.2 \\
\hline Causes of HF\# & \multicolumn{2}{|l|}{} \\
\hline Unhealthy foods & 201 & 71.8 \\
\hline Psychological factors & 172 & 61.4 \\
\hline Smoking & 110 & 39.3 \\
\hline Hypertension & 96 & 34.3 \\
\hline Genetics & 48 & 17.1 \\
\hline Obesity & 34 & 12.1 \\
\hline DM & 31 & 11.1 \\
\hline Don't know & 9 & 3.2 \\
\hline Severe anemia & 7 & 2.5 \\
\hline
\end{tabular}




\begin{tabular}{|c|c|c|}
\hline Items\# & No. $(n=280)$ & $\%$ \\
\hline \multicolumn{3}{|l|}{ Symptoms\# } \\
\hline Chest pain & 267 & 95.4 \\
\hline Difficult breathing & 262 & 93.6 \\
\hline Feeling tired or fainting & 147 & 52.5 \\
\hline Pain in shoulders and arm & 98 & 35.0 \\
\hline Swollen feet & 26 & 9.3 \\
\hline \multicolumn{3}{|l|}{ Eating special diet } \\
\hline Yes & 265 & 94.6 \\
\hline No & 15 & 5.4 \\
\hline \multicolumn{3}{|l|}{ Type of diet } \\
\hline Correct & 197 & 74.4 \\
\hline Incorrect & 68 & 25.6 \\
\hline \multicolumn{3}{|l|}{ Forbidden foods } \\
\hline Yes & 264 & 94.3 \\
\hline No & 16 & 5.7 \\
\hline \multicolumn{3}{|l|}{ Type of forbidden foods } \\
\hline Correct & 186 & 70.5 \\
\hline Incorrect & 78 & 29.5 \\
\hline \multicolumn{3}{|l|}{ Regular Checkup } \\
\hline Yes & 191 & 68.2 \\
\hline No & 89 & 31.8 \\
\hline \multicolumn{3}{|c|}{ General care for patients with heart failure\# } \\
\hline Diet & 123 & 43.9 \\
\hline Decrease stress & 79 & 28.2 \\
\hline Medications & 262 & 93.6 \\
\hline Follow-up & 58 & 20.7 \\
\hline Weight control & 16 & 5.7 \\
\hline Diabetes mellitus control & 3 & 1.1 \\
\hline hypertension control & 4 & 1.4 \\
\hline Stop smoking & 38 & 13.6 \\
\hline
\end{tabular}

${ }^{\#}$ More than one answer was selected

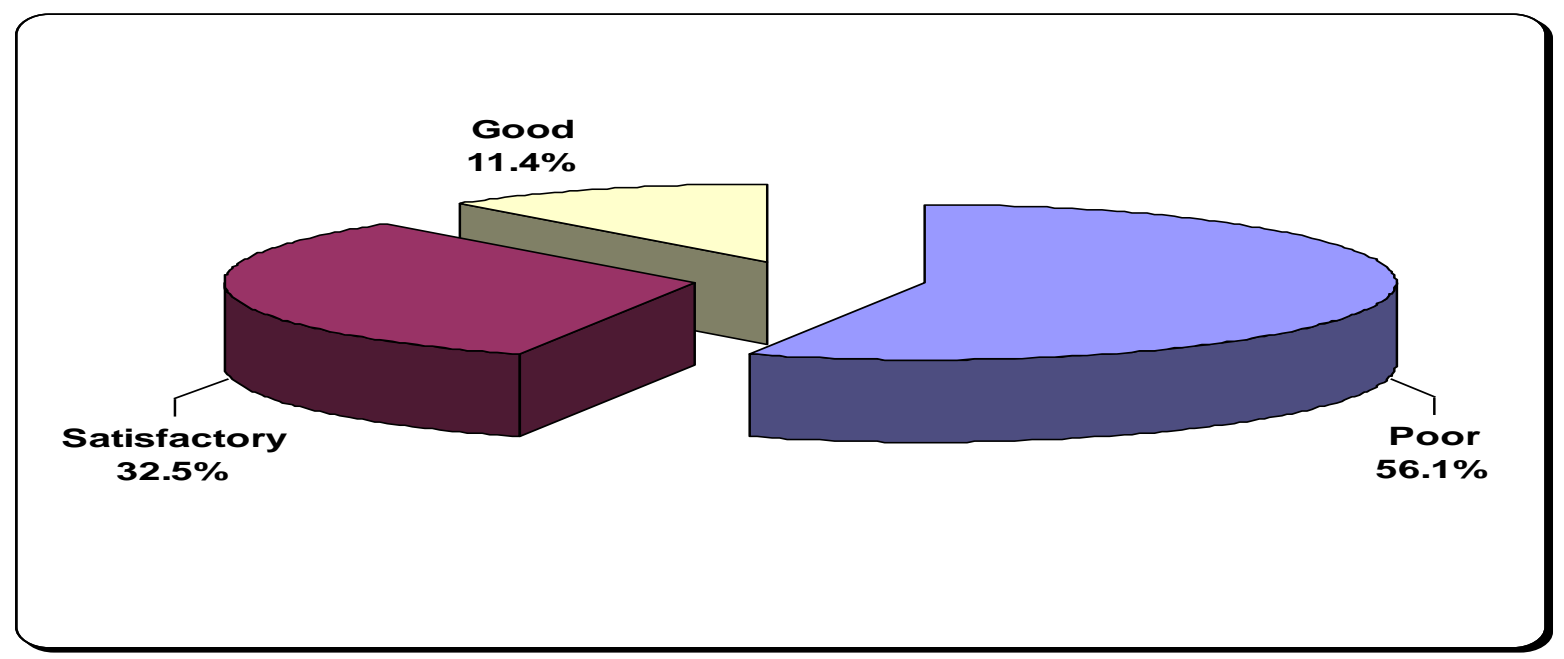

Figure (2): Distribution of geriatric patients with heart failure according to their knowledge score about heart failure. 


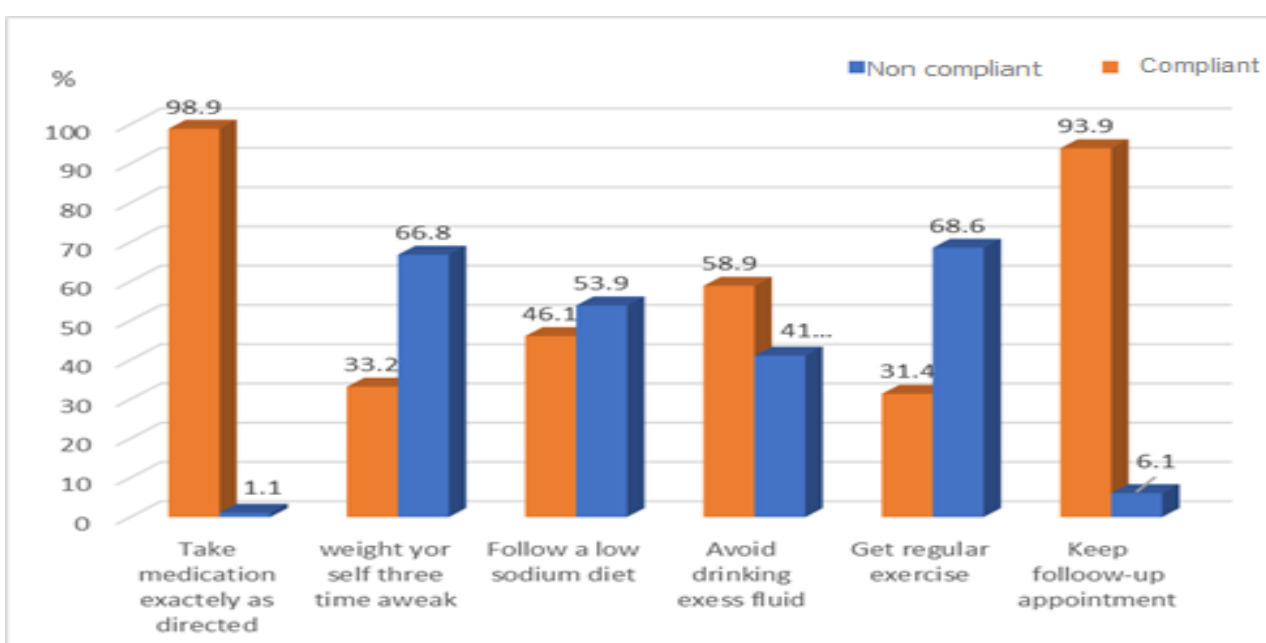

Figure (3): Distribution of studied sample according to therapeutic compliance about care of heart failure.

Table (4): Relation between sociodemographic characteristics of geriatric patients with heart failure and their compliance to therapeutic regimen.

\begin{tabular}{|c|c|c|c|c|c|c|c|c|c|c|c|c|}
\hline \multirow[t]{2}{*}{ Items } & \multicolumn{2}{|c|}{$\begin{array}{c}\text { Compliance } \\
\text { to take } \\
\text { medication }\end{array}$} & \multicolumn{2}{|c|}{$\begin{array}{l}\text { Compliance } \\
\text { to weigh daily }\end{array}$} & \multicolumn{2}{|c|}{$\begin{array}{c}\text { Compliance } \\
\text { to follow a } \\
\text { low sodium } \\
\text { diet }\end{array}$} & \multicolumn{2}{|c|}{$\begin{array}{c}\text { Compliance } \\
\text { to avoid } \\
\text { drinking } \\
\text { excess fluids }\end{array}$} & \multicolumn{2}{|c|}{$\begin{array}{l}\text { Compliance } \\
\text { to get regular } \\
\text { exercise }\end{array}$} & \multicolumn{2}{|c|}{$\begin{array}{l}\text { Compliance to } \\
\text { Keep follow-up } \\
\text { appointments }\end{array}$} \\
\hline & No. & $\%$ & No. & $\%$ & No. & $\%$ & No. & $\%$ & No. & $\%$ & No. & $\%$ \\
\hline \multirow{2}{*}{$\begin{array}{l}\text { Age } \\
60-65(158) \\
65-70(64) \\
70 \text { and more } \\
(58) \\
\text { P-Value }\end{array}$} & $\begin{array}{c}155 \\
64 \\
58 \\
\end{array}$ & $\begin{array}{c}98.1 \\
100.0 \\
100.0\end{array}$ & $\begin{array}{l}42 \\
22 \\
29 \\
\end{array}$ & $\begin{array}{l}26.6 \\
34.4 \\
50.0 \\
\end{array}$ & $\begin{array}{l}89 \\
30 \\
10 \\
\end{array}$ & $\begin{array}{l}56.3 \\
46.9 \\
17.2 \\
\end{array}$ & $\begin{array}{l}82 \\
36 \\
47 \\
\end{array}$ & $\begin{array}{l}51.9 \\
56.3 \\
81.0 \\
\end{array}$ & $\begin{array}{c}70 \\
17 \\
1 \\
\end{array}$ & $\begin{array}{c}44.3 \\
26.6 \\
1.7 \\
\end{array}$ & $\begin{array}{c}144 \\
61 \\
58 \\
\end{array}$ & $\begin{array}{c}91.1 \\
95.3 \\
100.0 \\
\end{array}$ \\
\hline & \multicolumn{2}{|c|}{0.310} & \multicolumn{2}{|c|}{0.005} & \multicolumn{2}{|c|}{0.000} & \multicolumn{2}{|c|}{0.001} & \multicolumn{2}{|c|}{0.000} & \multicolumn{2}{|c|}{0.047} \\
\hline \multirow{2}{*}{$\begin{array}{l}\text { Sex } \\
\text { Male (166) } \\
\text { Female (114) } \\
\text { P-Value }\end{array}$} & $\begin{array}{l}163 \\
114\end{array}$ & $\begin{array}{c}98.2 \\
100.0\end{array}$ & $\begin{array}{l}59 \\
34\end{array}$ & $\begin{array}{l}35.5 \\
29.8\end{array}$ & $\begin{array}{l}79 \\
50\end{array}$ & $\begin{array}{l}47.6 \\
43.9\end{array}$ & $\begin{array}{l}95 \\
70\end{array}$ & $\begin{array}{l}57.2 \\
61.4\end{array}$ & $\begin{array}{l}74 \\
14\end{array}$ & $\begin{array}{l}42.6 \\
12.3\end{array}$ & $\begin{array}{l}152 \\
111\end{array}$ & $\begin{array}{l}91.6 \\
97.4\end{array}$ \\
\hline & \multicolumn{2}{|c|}{0.273} & \multicolumn{2}{|c|}{0.318} & \multicolumn{2}{|c|}{0.538} & \multicolumn{2}{|c|}{0.485} & \multicolumn{2}{|c|}{0.000} & \multicolumn{2}{|c|}{0.046} \\
\hline \multirow{2}{*}{$\begin{array}{l}\text { Residence } \\
\text { Rural (205) } \\
\text { Urban (75) } \\
\text { P-Value }\end{array}$} & $\begin{array}{c}202 \\
75\end{array}$ & $\begin{array}{c}98.5 \\
100.0\end{array}$ & $\begin{array}{l}61 \\
32\end{array}$ & $\begin{array}{l}29.8 \\
42.7\end{array}$ & $\begin{array}{c}101 \\
28\end{array}$ & $\begin{array}{l}49.3 \\
37.3\end{array}$ & $\begin{array}{c}118 \\
47\end{array}$ & $\begin{array}{l}57.6 \\
62.7\end{array}$ & $\begin{array}{l}58 \\
30\end{array}$ & $\begin{array}{l}28.3 \\
40.0\end{array}$ & $\begin{array}{c}193 \\
70\end{array}$ & $\begin{array}{l}94.1 \\
93.3\end{array}$ \\
\hline & \multicolumn{2}{|c|}{0.567} & \multicolumn{2}{|c|}{0.042} & \multicolumn{2}{|c|}{0.076} & \multicolumn{2}{|c|}{0.442} & \multicolumn{2}{|c|}{0.062} & \multicolumn{2}{|c|}{0.782} \\
\hline $\begin{array}{l}\text { Pt. } \\
\text { Education } \\
\text { Illiterate } \\
(119) \\
\text { Read \& write } \\
\text { (47) } \\
\text { Primary (34) }\end{array}$ & $\begin{array}{c}117 \\
47 \\
33 \\
34 \\
32 \\
14 \\
\end{array}$ & $\begin{array}{c}98.3 \\
100.0 \\
97.1 \\
100.0 \\
100.0 \\
100.0 \\
\end{array}$ & $\begin{array}{c}30 \\
13 \\
9 \\
9 \\
22 \\
10 \\
\end{array}$ & $\begin{array}{c}30 \\
13 \\
9 \\
9 \\
22 \\
10 \\
\end{array}$ & $\begin{array}{l}57 \\
24 \\
20 \\
14 \\
9 \\
5 \\
\end{array}$ & $\begin{array}{l}47.9 \\
51.1 \\
58.8 \\
41.2 \\
28.1 \\
35.7 \\
\end{array}$ & $\begin{array}{c}66 \\
28 \\
20 \\
24 \\
19 \\
8 \\
\end{array}$ & $\begin{array}{l}55.5 \\
59.6 \\
58.8 \\
70.6 \\
59.4 \\
57.1 \\
\end{array}$ & $\begin{array}{l}19 \\
15 \\
17 \\
13 \\
15 \\
9 \\
\end{array}$ & $\begin{array}{l}16.0 \\
31.9 \\
50.0 \\
38.2 \\
46.9 \\
64.3 \\
\end{array}$ & $\begin{array}{l}112 \\
45 \\
30 \\
32 \\
31 \\
13 \\
\end{array}$ & $\begin{array}{l}94.1 \\
75.7 \\
88.2 \\
94.1 \\
96.9 \\
92.9 \\
\end{array}$ \\
\hline $\begin{array}{l}\text { Preparatory } \\
(34) \\
\text { Secondary } \\
(32 \\
\text { University } \\
(14) \\
\text { P-Value } \\
\end{array}$ & \multicolumn{2}{|c|}{0.713} & \multicolumn{2}{|c|}{0.000} & \multicolumn{2}{|c|}{0.160} & \multicolumn{2}{|c|}{0.772} & \multicolumn{2}{|c|}{0.000} & \multicolumn{2}{|c|}{0.742} \\
\hline \multirow{2}{*}{$\begin{array}{l}\text { Social Class } \\
\text { Low (46) } \\
\text { Middle (183) } \\
\text { High (51) } \\
\text { P-Value }\end{array}$} & $\begin{array}{c}46 \\
180 \\
51\end{array}$ & $\begin{array}{c}100 \\
98.4 \\
100\end{array}$ & $\begin{array}{l}11 \\
52 \\
30\end{array}$ & $\begin{array}{l}23.9 \\
28.4 \\
58.8\end{array}$ & $\begin{array}{l}17 \\
95 \\
17\end{array}$ & $\begin{array}{l}37.0 \\
51.9 \\
33.3\end{array}$ & $\begin{array}{c}30 \\
106 \\
29\end{array}$ & $\begin{array}{l}65.2 \\
57.2 \\
56.9\end{array}$ & $\begin{array}{c}3 \\
59 \\
26\end{array}$ & $\begin{array}{c}6.5 \\
32.2 \\
51.0\end{array}$ & $\begin{array}{c}45 \\
170 \\
48\end{array}$ & $\begin{array}{l}97.8 \\
92.9 \\
94.1\end{array}$ \\
\hline & \multicolumn{2}{|c|}{$\begin{array}{lll} & & \\
& 0.448\end{array}$} & \multicolumn{2}{|c|}{$\frac{1}{0.000}$} & & & & & & & & \\
\hline
\end{tabular}

Chi-square test

There is significant difference - Significant at $P<0.05$ 
Table (5): Relation between total knowledge score and therapeutic compliance among studied elderly patients with heart failure diseases.

\begin{tabular}{|c|c|c|c|c|c|c|c|}
\hline \multirow{3}{*}{ Items } & \multicolumn{6}{|c|}{ Level of knowledge } & \multirow{3}{*}{ P-value } \\
\hline & \multicolumn{2}{|c|}{ Poor } & \multicolumn{2}{|c|}{ Satisfactory } & \multicolumn{2}{|c|}{ Good } & \\
\hline & No. & $\%$ & No. & $\%$ & No. & $\%$ & \\
\hline & \multirow{3}{*}{0.305} \\
\hline $\begin{array}{l}\text { exactly as directed? } \\
\text { Compliant }\end{array}$ & 154 & 98.1 & 91 & 100.0 & 32 & 100.0 & \\
\hline Non-compliant & 3 & 1.9 & 0 & 0.0 & 0 & 0.0 & \\
\hline \multicolumn{7}{|c|}{ Do you weigh yourself daily? Or at } & \multirow{3}{*}{$0.000 *$} \\
\hline $\begin{array}{l}\text { least three times a week } \\
\text { Compliant }\end{array}$ & 26 & 16.6 & 46 & 50.5 & 21 & 65.6 & \\
\hline Non-compliant & 131 & 83.4 & 45 & 49.5 & 11 & 34.4 & \\
\hline \multicolumn{7}{|c|}{ Do you follow a low sodium diet? } & \multirow{3}{*}{$0.000 *$} \\
\hline Compliant & 96 & 61.1 & 26 & 28.6 & 7 & 21.9 & \\
\hline Non-compliant & 61 & 38.9 & 65 & 71.4 & 25 & 78.1 & \\
\hline \multicolumn{7}{|c|}{ Do you avoid drinking excess fluids? } & \multirow{3}{*}{$0.005^{*}$} \\
\hline Compliant & 81 & 51.6 & 66 & 72.5 & 18 & 56.3 & \\
\hline Non-compliant & 76 & 48.4 & 25 & 27.5 & 14 & 43.8 & \\
\hline \multicolumn{7}{|c|}{ Do you get regular exercise? } & \multirow{3}{*}{$0.000 *$} \\
\hline Compliant & 31 & 19.7 & 39 & 42.9 & 18 & 56.3 & \\
\hline Non-compliant & 126 & 80.3 & 52 & 57.1 & 14 & 43.8 & \\
\hline \multirow{2}{*}{$\begin{array}{l}\text { Do you Keep follow-up } \\
\text { appointments? } \\
\text { Compliant } \\
\end{array}$} & & & & & & & \multirow{3}{*}{$0.020 *$} \\
\hline & 142 & 90.4 & 89 & 97.8 & 32 & 100.0 & \\
\hline Non-compliant & 15 & 9.6 & 2 & 2.2 & 0 & 0.0 & \\
\hline
\end{tabular}

Chi-square test

There is significant difference - Significant at $P<0.05$

Table (1): Illustrates that the age $56.4 \%$ of studied subjects ranged from $60-65$ years old with a mean of age $65.10 \pm 6.12$ and shows that $40.7 \%$ were females. Subjects living in the rural areas accounting $73.2 \%$ and living with their relatives accounting $98.2 \%$. This table reveals that $5.0 \%$ had university education, $20.7 \%$ were un employed, and $65.4 \%$ are from middle social class, $54.3 \%$ of geriatric patients have caregivers .

Figure (1): Illustrates that $28.6 \%$ of the studied sample had hypertension, while $20.0 \%$ had renal disease, $17.1 \%$ had diabetes mellitus and $6.1 \%$ were smokers.

Table (2): Illustrates that $96.4 \%$ and $85.7 \%$ respectively of studied patients complain from difficulty in breathing and chest pain. Also, the table illustrates that $4.6 \%, 28.6 \%$ respectively of them used pacemaker and had previous heart operation while $32.9 \%$ of them had duration of disease more than 4 years.

Table (3): Reveals that $53.2 \%$ of studied sample don't know what heart failure is, and $71.8 \%$ of them said that unhealthy foods caused heart failure, $95.4 \%$ and $93.6 \%$ respectively of them said that chest pain and difficult breathing was the main symptoms of heart failure disease. While $94.6 \%$ and of studied patients knew that heart failure patients had therapeutic diet. This table also, concerning regular checkup, table III illustrated that more than two thirds $68.2 \%$ of studied subjects maintain regular checkup.

Figure (2): Shows that $56.1 \%$ of the studied sample had poor knowledge's scores and $32.5 \%$ of them had satisfactory score, while (11.4\%) of them had good score of knowledge about heart failure.

Figure (3): Shows that $98.9 \%$ committed to medications and $93.9 \%$ of them committed keep follow up. While $66.8 \%$ of studied patient didn't weight themselves, and $53.9 \%$ of studied sample didn't follow low sodium diet.

Table (4): Shows relation between patient's therapeutic compliance and socio demographic characteristics. It was found that $34.4 \%$ of patients were compliant to measuring weight at age group 65 - < 70 and $56.3 \%$ of patients were compliant to eat low sodium diet in age group $60>65$ with statistical difference at all items except complaint to take medication $\mathrm{P}=0.310$.

Also, it found that $35.5 \%$ of patients were compliant to measuring weight were male and $97.4 \%$ of patients were female compliant to keep follow up appointment with statistical significant difference at 
only get regular exercise and keep follow up $\mathrm{P}=$ 0.000 and 0.046 respectively.

According to residence, it was found that $100.0 \%$ of patients were compliant take medication lived in urban area and $94.1 \%$ of patients were compliant to keep follow up were lived in rural area with statistical significant difference only at weight daily or at least three times per week. Also, shows that statistical significant difference on education at weight daily or three times per week $\mathrm{p}=0.000$ and at get regular exercise $\mathrm{p}=0.000$. According social class this table shows that statistical significant difference at weight daily or three times per week P0.000 and at get regular exercise $\mathrm{p}=0.000$.

Table (5): Shows relation between patient's compliance and total knowledge score level among heart failure patients, it was found that $100.0 \%$ of patients had good knowledge were compliant to keep follow up and take medication and $100.0 \%$ and $97.8 \%$ respectively of them had satisfactory knowledge were complaint to take medication and keep follow up.

\section{Discussion}

One of the most serious problems encountered among patients with HF is non-adherence to therapeutic regimen care because of its unavoidable outcomes, deteriorating signs and increasing frequency of hospital readmission (AL-khadher \& Fadl-Elmula 2015) The chief rates of non-compliance were low sodium intake, fluid limit, measuring weight and practicing exercise.

The present study aimed to assess therapeutic compliance among geriatric patients with heart failure.

The present study showed that the mean age of studied sample was $65.10 \pm 6.12$ years. This result is similar to that conducted by (Ogbemudia \& AsekhameJ, 2016) who studied rehospitalization of geriatric patients with heart failure and reported that mean age of $74 \pm 7.33$ years. The present study showed that about three fifth of studied sample were male this indicate heart failure was more common among male than female. Similar findings reported by (ALkhadher \& Fadl-Elmula 2015) who study factors affecting treatment compliance of heart failure Patients in Sudan and noticed that men were more likely than women to suffer from heart failure, and more than half of participants were male.

This study indicated that the great part of participants lived in the country regions with their relatives and this is in agreement with a study conducted by Yu et al., (2016) applied at china and reported that three quarter of participants lived with their families.

This recent research exposed that more than two fifths of participants were uneducated, it can be understood by the great section of them lived in the country zone and this study disagreed with Mbakwem et al., (2013) who demonstrated that $8.4 \%$ of participants were illiterate.

This existing study exposed that more than half of participants had person who give care to them. This existing research clarified that more than one-fifth of participants had history of hypertension and one fifth of them had history of renal disorders. This may be related to that the elderly chronic illness as hypertension and renal diseases increases risk of heart failure and this study agreed with Bui et al., (2011) who founded that one third of participants had history of hypertension.

This study indicated that more than half of participants don't know what is the HF, great part of participants said that unhealthy food could make HF, the majority of participants said that chest pain is the chief indications of HF. the great part of participants said that HF need regular checkup, the great part of participants said that drugs is the chief effective general measure of HF.

$\mathrm{HF}$ is compound condition that leads to noticeable increasing of hospital admission that can associate with poor compliance to treatment. (Silva et al., 2015) This existing study indicated that adherence with drugs and follow up was elevated because most of participants were treated state expenditure and this agreed with (AL-khadher \& Fadl-Elmula 2015) who reported adherence with drugs and follow up was elevated, and this disagrees with (Ogbemudia \& Asekhame, 2016) who reported that the elderly had poor adherence with pharmological management.

This study exposed more than half of the participants were non-adherence with low sodium intake. This study agreed with study by (Zhang et al., 2015) applied at Canada and reported that more than three fifths of the participants were non-adherence with diet.Also this study agreed with AL-khadher \& Fadl-Elmula (2015) who reported the great part of participants was nonadherence with low salt intake. This study disagrees with Nieuwenhuis et al., (2011) who studied the body of knowledge on compliance in heart failure patients we are not there yet and reported that the most of the participants were adherence with sodium diet.

This study indicated that more than three fifths of the participants were non-adherence to assessing weight every day or 3 times a week. This study agreed with (Zhang et al., 2015) who reported that more than three quarters of the studied samples were nonadherence with measuring weight. Also, this study agreed with (AL-khadher \& Fadl-Elmula 2015) who reported the great part of participants was nonadherence to assessing weight day by day. 
This existing study indicated more than three fifths of the studied samples were non-adherence to get regular exercise. This study agreed with (Zhang et al., 2015) who reported that the great part of participants was nonadherence with exercise. Also, this study agreed with AL-khadher \& Fadl-Elmula (2015) who reported the majority of studied sample were nonadherence with regular exercise.

The present study showed that around three fifths of studied sample were adherence with water limit. This study agreed with Nieuwenhuis et al., (2011) who reported that adherence with fluid restriction was high. This study disagreed with AL-khadher \& Fadl-EImula (2015) who reported that the great part of participants were non-adherence with liquid limit. This existing study indicated that Adherence with low sodium diet, water limit, exercise and measuring weight day by day was low and this attributed to patients thought cannot be treated, decreasing of knowledge to commit with the nutritional limitations, decreasing of knowledge to weight and preventing over fluid volume.This agrees with AL-khadher \& Fadl-EImula (2015) that reported non-adherence may come from decrease of awareness and teaching ill people. Even though information is vital to advance adherence and altering wrong views about the routine.

\section{Conclusion}

Heart failure increases with age. Low social class patients have poor knowledge about heart failure. Female patients were noncompliant to measuring weight; eat low sodium diet, doing regular exercise (walking). Patients lived in rural areas were noncompliant to measuring weight; eat low sodium diet, doing regular exercise. Low social class patients are associated with noncompliance to measuring weight and doing regular exercise.

\section{Recommendations}

More studies should be implemented to assess therapeutic compliance, health education program for elderly about therapeutic compliance about heart failure. More attention should be paid to know trouble and difficulties with Adherence of $\mathrm{HF}$ patients and aid them to manage these problems.

\section{References}

1. Abdel Tawab A., (2004): Family Socio economic Status Scale, journal of scientific magazine, 20(2), pp.35-48.

2. Alama M., (2017): Aging-Related Changes of the Cardiovascular System, Journal of Health and Environmental Research, 3(2),p.27.

3. AL-khadher M., \& Fadl-Elmula I., (2015): Factors Affecting Treatment Compliance of
Heart Failure Patients in Sudan, Public Health and Preventive Medicine, 1( 3), pp. 120-21

4. Bolton E., \& Raj Kumar C., (2011): The ageing cardiovascular system, Reviews in Clinical Gerontology, 21(2), pp.99-101

5. Bui A., Horwich T., \& Fonarow G., (2011): Epidemiology and risk profile of heart failure, Nature Reviews Cardiology, 8(1), p.p 1-7 Available at http:// www.ncbi.nlm.gov/pmc/article/phpm.

6. Burggraf V., Kim K., \& knight A., (2014): Health aging principles and clinical practice for clinicians, cardiovascular disease, printed in china; p.54-5

7. Chan H., Yu D., Leung D., Chan A., \& Hui E., (2016): Quality of life and palliative care needs of elderly patients with advanced heart failure, Journal of Geriatric Cardiology, 13(5), p.420

8. Chen H., \& Chen C., (2017): Factors Associated with Quality of Life Among Older Adults with Chronic Disease in Taiwan, International Journal of Gerontology, 11(1), pp.12-15

9. Elbadway A., \& El Hefnawy K., (2013): Randomized controlled trial of comprehensive nursing intervention on readmission, mortality and quality of life among Egyptian heart failure patients A 12 month follow up study, Journal of Nursing Education and Practice, 3(5) p. 15 available at: www.sciedu.ca/jnep.

10. Hoekstra T., Jaarsma T., Veldhuisen D., Hillege H., Sanderman R., \& Leegte I., (2013): Quality of life and survival in patients with heart failure, European Journal of Heart Failure; 15 (1),pp 94-102

11. Karavidas A., Lazaros G., Tsiachris D., \& Pyrgak V., (2010): Aging and the Cardiovascular System, Hellenic Journal of Cardiology, 51(5), pp421-7

12. Kazer M., \& Murphy K., (2015): Nursing case studies on improving health related quality of life in older adults, cardiovascular health promotion, springer publishing company, printed in Printed in the United States of America by Gasch Printing. p.372-372

13. Mbakwem A., Aina F., Amadi C., Akinbode A., \& Mokwunyei J., (2013): Comparative analysis of the quality of life of heart failure patients in South Western Nigeria, World Journal of Cardiovascular Diseases ; 3, (1), pp. 146-53

14. Nieuwenhuis, Van Der Wal M., \& Jaarsma T., (2011): The body of knowledge on compliance in heart failure patients we are not there yet, Journal of Cardiovascular Nursing ; 26( 1), pp 21

15. Ogbemudia E., \& Asekhame J., (2016): Rehospitalization for heart failure in the Elderly, 
Saudi Medical Journal; 37(10),pp. 1144-47 available at www.smj.org.sa

16. PI HY., \& HU X., (2016): Nursing care in old patients with heart failure: current status and future, Journal of Geriatric Cardiology; 13( 5), p.387.

17. Silva A., Cavalcanti A., Malta M., Arruda G., GandinT., Fé A., \& Rabelo-Silva E., (2015): Treatment adherence in heart failure patients followed up by nurses in two specialized clinics , Rev. Latino-Am., Enfermagem; 23( 5), p. 889

18. Walker B., Colledge N., Ralston S., \& Penman I., (2014):Davidson's Principles and Practice of medicine, cardiovascular disease, 22 th ed, Elsevier Health Sciences, Printed in China, p.548 5-551

19. WHO (world health organization 2015): World report on ageing and health, healthy ageing, p.25, 28.

20. Yu D., Chan H., Leung D., Hui E., \& Sit J.,(2016): Symptom clusters and quality of life among patients with advanced heart Failure, Journal of Geriatric Cardiology; 13(5),pp. 40814

21. Zhang K., Dindoff K., Arnold M., Lane J., \& Swartzman L., (2015): What matters to patients with heart failure? The influence of non-healthrelated goals on patient adherence to self-care management, Patient Education and Counseling ; 98 (8),pp.927-34 